The Effect of Industry Specific Factors on the Profitability of Companies...

DR/ Ahmed Fouad Hassaballa \& Shereen Fadel Fahmy Bishara

\title{
The Effect of Industry Specific Factors on the Profitability of Companies Listed in the Egyptian Securities Market (An Empirical Study)
}

Prepared by, in alphabetical order:

Ahmed Fouad Hassaballa

Lecturer of Finance \& Accounting

Arab Academy for Science and Technology \& Maritime Transport, Dokki, Cairo branch

Hassabo78@hotmail.com

Shereen Fadel Fahmy Bishara

Lecturer of Finance \& Accounting

Arab Academy for Science and Technology \& Maritime Transport, Dokki, Cairo branch

Shereenfadel@gmail.com

\section{1- Introduction}

Profitability is one of the main objectives and its sustainability is necessary for the long term survival of any firm .That is why profitability differs among different firms.

Earlier views concerning profitability differences was of Industrial Organization (IO). The traditional industrial organization approach follows an -outside-in perspective regarding the effect of market (Industry) structure on firm performance .Firms in a specific industry may earn comparatively above average profits due to certain industry structural variables. The basic model working behind is the Structure-Conduct-Performance (SCP) paradigm .This model states that a firm's performance is influenced by its conduct in

المجلد الحادي عشر


The Effect of Industry Specific Factors on the Profitability of Companies...

DR/ Ahmed Fouad Hassaballa \& Shereen Fadel Fahmy Bishara

different matters such as investment, research and development and pricing. The behavior of the firm in turn depends on industry structure .Industry structural characteristics include the number of producers, the percentage of concentration, product differentiation, entry and mobility Barriers, etc ...

In other words, the structural characteristics of any industry affect behavior (strategies) and profitability of its constituent firms .Here the firm's management role is unimportant .Because firm's conduct is driven by the specific industry structural characteristics so management cannot play any role in improving the firm's performance. Concentration is one of the most important market structural elements .It is generally believed that highly concentrated industries are characterized by higher returns .Member firms exhibit collusive behavior instead of competitive which leads to greater market power and control over prices and hence profits .Concentration leads to high profits only when there are barriers to entry .Because high profits will attract new entities, as the number of firms increase, concentration level will fall, market power will decline and prices will get closer to the marginal cost and ultimately profits will fall .The industrial organization view also surmounts that each industry is liable to similar leverage ratios, liquidity ratios, growth figures and many other features that could all result in similar profitability figures for most of the companies operating in that industry.

المجلد الحادي عشر


The Effect of Industry Specific Factors on the Profitability of Companies...

DR/ Ahmed Fouad Hassaballa \& Shereen Fadel Fahmy Bishara

\section{2- Objective of the Research}

The objective of this research is to test for factors that affect firm profitability, and to create an effective model, which when used by prospective companies in the market could help to increase and improve profitability. Another objective of this research is to prove whether the theory of industrial organization actually exists in the Egyptian market or not.

\section{3- Literature Review}

The foundation of IO perspective depends on the hypothesis that inter-industry profitability differences are greater than intraindustry differences . The importance of industry as a determinant of firm profitability dates back to the 1930s .Mason (1939) gave his view that industry structure determines firm profitability . Later on, Bian (1956) explained the Mason's view that industrylevel entry barriers restrict potential entrants that results in reduced competition and greater profitability .Likewise, Porter's (1980) competitive forces framework contributed to the importance of industry structural elements in explaining firm profitability .Each of the Porter's five forces the threat of the new entrants, the bargaining power of the buyers and suppliers, competitive rivalry and the threat of the substitute products determine the cost, price and investment requirements. 
The Effect of Industry Specific Factors on the Profitability of Companies...

DR/ Ahmed Fouad Hassaballa \& Shereen Fadel Fahmy Bishara

Porter's Model accesses the industry attractiveness, which in turn explains the overall industry profitability and ultimately the profitability of firms operating in that industry .Schmalensee (1985) using the profitability data of 456 American manufacturing firms for the single year (1975) found that industry effect explained about $19.5 \%$ of variation in the business unit profitability .Wernerfelt and Montgomery (1988) also found industry effect most important .On the other hand, accounting and finance literature also stands important in explaining firm profitability .The accounting and finance literature suggests that the reasons for the existence of more and less profitable firms within the same industry must be found in internal factors of each firm .These firm specific internal factors include age, size, leverage, growth, liquidity etc .Goddard et al .(2005), Hecht (2008) and many other researchers using financial data explored the impact of different firm specific sources in profitability variation.

\section{3-1 Industry effect :}

Sources for variation in firm profitability in industrial organization literature focus on industry specific factors; number and distribution of the size of producers (concentration), control over product prices, entry and exit and mobility barriers .Early researchers Mason (1939 )and Bian (1956 )viewed that industry structural characteristics influence firm profitability .

المجلد الحادي عشر


The Effect of Industry Specific Factors on the Profitability of Companies...

DR/ Ahmed Fouad Hassaballa \& Shereen Fadel Fahmy Bishara

Schamalensee (1985 )using the profitability data of 456 American manufacturing firms for the single year (1975) found that industry effect is dominant, contributing $19.5 \%$ in the firm profitability .Using Tobin's q as a proxy for the profitability, Montgomery and Wernerfelt (1988) viewed industry effect as the most important factor explaining $20.1 \%$ variation in the profitability .Claver et al) 2002 (using the data of 679 Spanish manufacturing firms for the period of 1994-98 found that transient industry effect dominates over stable effect explaining $2.78 \%$ variation in the profitability, whereas stable industry effects explained $2.06 \%$ and $0.36 \%$ variation in the profitability . Wiggins and Ruefli (2003) using a sample of 2496 firms for the period of 1980-96 revealed that industry effect is negligible explaining only $0.1 \%$ variation in the profitability .Goddard et al . (2009) using the data of 11 European member countries found that year, stable and transient industry effects accounted for $0.34 \%, 2.92 \%$ and $2.35 \%$ variance in the profitability respectively.

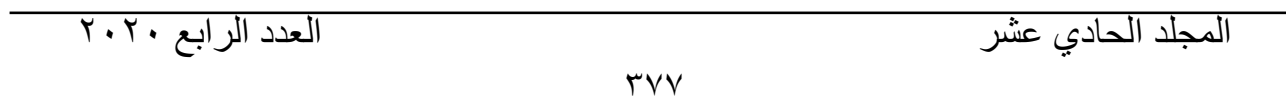


The Effect of Industry Specific Factors on the Profitability of Companies...

DR/ Ahmed Fouad Hassaballa \& Shereen Fadel Fahmy Bishara

\section{3-2 Size :}

Past theories of firm size predict positive relationship between size and profitability .But the review of literature yielded mix findings .Nunes et al .(2009) quoting Gschwandtner (2005), Hard Wick (1997), Winter (1994), and Wyn (1998) emphasized firm size as an important determinant of profitability .Large firms take cost advantage (economics of Scale), diversify their products, create entry Barriers for new firms and have a great power to bear risk arising from different changes in the market place, which results in increased rate of profits .Majumdar (1997)stated that in large organizations process formalization and effective operations implementation results in superior performance as compared to small firms quoting ( Penrose, 1959 ).

Nazir (2009 ) using the data of 204 non-financial firms listed on KSE from 1998 to 2005 found significant positive relationship between firm size and profitability .Hall and Weiss (1967) also found the same results .Kaen and Baumann (2003 )using the data of 64 American manufacturing industries from 1999-2001 found that in half of the industries relationship between size and profitability was positive but when firms become much larger there exist no relationship because advantages of economies of scale are offset by organizational cost .Stekler (1964) exploring relationship between firm size and time Variability of profits found that medium sized firms experience greater changes in

المجلد الحادي عشر


The Effect of Industry Specific Factors on the Profitability of Companies...

DR/ Ahmed Fouad Hassaballa \& Shereen Fadel Fahmy Bishara

profits .Marcus (1969 )found very small effect of size on firm profitability .Jensen and Murphy (1990) argued that, in large organizations managers feel their Jobs more secure and prioritize their personal motives instead of firm financial performance that leads to decrease in profitability .Dhawan (2001) also found inverse relationship between firm size and profitability . Samiloglu and Demirgunes (2008) found no relationship between size and profitability.

\section{3-3 Age :}

Regarding the impact of Age on the firm profitability, one view is that older firms have more knowledge, take the benefits of learning, and overcome the deficiencies of newness and ultimately perform better (Majumdar, 1997) , quoting (Stinchcombe, 1965) .Arrow (1962) viewed that age contributes positively to firm efficiency. With the passage of time firms discover their expertise, learn how to do things better, standardize their operations, reduce cost and enhance productivity and quality. The other view states that as the firms get older they become inflexible and lack adapting to changes in the environment than the younger firms and lose their performance )Marshall, 1920 .(Loderer and Waelchli (2009) found that age impairs the firm profitability .As firms get older they lose their competitive advantage )cost rises and margin falls,

\footnotetext{
المجلد الحادي عشر 
The Effect of Industry Specific Factors on the Profitability of Companies...

DR/ Ahmed Fouad Hassaballa \& Shereen Fadel Fahmy Bishara

investment in research and development activities falls and assets become obsolete.

\section{Growth :}

It is generally assumed that growth is essentially a prerequisite for the profitability .Capon et al( 1990) applying meta-analysis to 320 published studies concluded that growth, market share, low level of debt and capital investment in the business unit leads to high profitability .During his work he found 88 studies in which growth was positively related to profitability .Geroski et al . (1997) argued that firm's current growth rate reflects expectations about the future profits .Using the data of $271 \mathrm{UK}$ firms from 1976-1982, they found positive and statistically significant relationship between current growth rates and future profitability . Bothwell et al) .1984 (and Samiloglu and Demirgunes (2008) also found positive relationship between growth and profitability . Ramezani et al ( 2002) found that there exists an optimal level of growth )sales growth(; up to that level firm profitability increases, beyond that level growth negatively affects profitability .Markman and Gartner (2002) using sales and no .of employees as a measure of growth found surprising results that high growth was not related to the firm profitability. While age and profitability relationship was significantly negative showing that younger firms earn slightly higher profit than older one . Amir and Sana (2006) using five year data (2001-2005) of listed

المجلد الحادي عشر


The Effect of Industry Specific Factors on the Profitability of Companies...

DR/ Ahmed Fouad Hassaballa \& Shereen Fadel Fahmy Bishara

firms of oil and gas sector of Pakistan found negative relationship between growth and profits .They argued that this abnormal relationship may be due to reason of huge investment required initially along increase in sales, which decreases the profits .

\section{3-5 Market Share :}

Gale (1972) and Buzzell et al) .1975 (viewed that high market share offers many advantages such as market share based product differentiation, increased bargaining power and economies of scale .These factors explain direct influence of market share on firm profitability .Ravenscraft (1983)(, Venkatraman and Prescott )1990 (found that firms having high market share earn high profits .Szymanski et al) 1993 (also suggested positive association of market share and business unit profitability .Faria and Wellington (2004) using the data of 3800 firms working in 96 industries found statistically significant and positive relationship between share in the market where a firm serves and profitability .Goddard et al) .2005 (found stronger direct relationship between market share and profitability in European manufacturing arguing that there is a tendency in European firms to engage in advertising and promotional strategies to capture market share and discourage new entrants .Cooper and Woo (1982) found low market share firms highly profitable .They reasoned that these Low-MS and highly profitable firms were operating in stable and highly competitive environment, offering

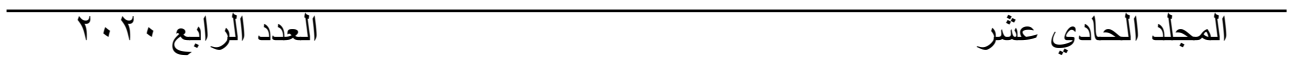


The Effect of Industry Specific Factors on the Profitability of Companies...

DR/ Ahmed Fouad Hassaballa \& Shereen Fadel Fahmy Bishara

highly value-added products and their parent companies had healthy financial position. The market share and profitability relationship is not so much straight forward; Feeny (2000) found U-shape relationship between market share and profitability . Small firms take advantage of niche marketing and flexibility, while the large firms having market share greater than $30 \%$ earn high profits .

\section{3-6 Leverage :}

Past studies have shown both the positive and negative effect of leverage on the firm profitability .Linking this issue with the Agency theory, the conflict of interest between owners and managers results in significant agency cost, to resolve this problem owners can increase the level of debt and can reduce the amount of free cash flows available to managers, hence reducing agency cost leverage exerts a positive impact on the firm profitability (Mork et al., 2007), quoting ( Meckling and Jensen, 1976) . In the absence of agency cost, debt also has an effect on the firm performance because lenders continuously monitor the firm performance to reduce their risk and there is a stress on the management to improve their performance to prevent liquidation, management becomes efficient and invests free cash in positive NPV projects )Grossman and Hart, 1982 .(Jensen )1986 (also suggested that leverage has a positive effect on firm performance . Eriotis et al) .2002 (found negative relationship between leverage

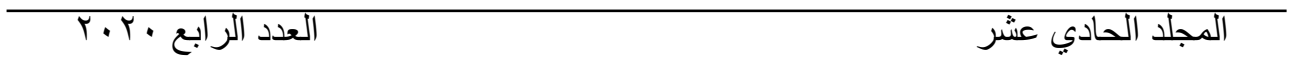


The Effect of Industry Specific Factors on the Profitability of Companies...

DR/ Ahmed Fouad Hassaballa \& Shereen Fadel Fahmy Bishara

and profitability . This negative relationship may be due to the reason that highly leveraged firms bear high cost of borrowed capital than its returns and hence less profitable .- The reduced capacity of businesses to invest in profitable projects and take advantage of good investment opportunities, a consequence of the need to pay debt charges periodically, can mean diminished firm profitabilityll ( Goddard et al., 200) .Samiloglu and Demirgunes (2008) found leverage negatively affecting firm profitability reasoning that highly leveraged firms have insufficient power to compete that leads to decrease in their profitability, quoting Myers (2003) .Hall and Weiss (1967) and Baker (1973) also provided empirical evidences to support negative relationship of leverage and profitability.

\section{3-7 Liquidity :}

Conventionally all text books of finance stress negative relationship between liquidity and profitability that low proportion of current assets )near to cash (results in high rate of return but many researchers have explored opposite to that statement in their studies .High liquidity reduces the risk of unavailability of funds to repay short term obligations, contributing positively to the firm profitability (Deloof, 2003 .) According to Goddard et al) 2005 (liquid firm are more profitable because they are in better position to capture growth opportunities and cope with unpredictable market changes .Fama

المجلد الحادي عشر


The Effect of Industry Specific Factors on the Profitability of Companies...

DR/ Ahmed Fouad Hassaballa \& Shereen Fadel Fahmy Bishara

and Jensen )1983 (viewed that greater liquidity leads to the agency problem between owners and Managers .Eljelly (2004) viewed that efficient liquidity management refers to handling currents assets and current liabilities in such a way that it reduces the risk of default .Applying correlation and regression analysis to a sample of Saudi joint stock firms he found negative relationship between liquidity and profitability .Raheman and Nasr )2007 (using the six years data of 94 Pakistani firms from 1999-2005 listed on Karachi stock exchange also found that greater level of liquidity leads to decreased profitability because of the fact that high investment in current assets is not utilized efficiently, suggesting managers not to increase the liquidity to increase the profitability of the firm .

Eriotis et al( 2002) suggested that highly levered firms bear high cost of debt that reduces its returns .Size is the second most important variable significantly and positively affecting, explaining more than $6 \%$ variation in the profitability .Large firms formalize their processes, implement operations effectively and take cost advantage that results in increased profitability . Nazir (2009) also found positive relation of size with firm profitability for non-financial Pakistani firms .Liquidity is another variable having negative impact on firm profitability . Results imply that profitability can be increased by reducing the level of liquidity .Raheman and Nasr (2007 )explaining the negative relationship of liquidity in Pakistani firms suggested

العدد الرابع •r.r

المجلد الحادي عشر 
The Effect of Industry Specific Factors on the Profitability of Companies...

DR/ Ahmed Fouad Hassaballa \& Shereen Fadel Fahmy Bishara

that huge investment in current assets is not utilized efficiently and reduces the returns .The relationship of lag sales growth with the profitability is found positive, explaining $0.062 \%$ variation in the profitability.

Geroski et al) .1997 (argued that firm's current growth rate reflects expectations about the future profits and its effect is positive .The positive relationship of market share and profitability is the result of some gains like economies of scale, monopoly or bargaining power. This finding is similar to the results of )Goddard et al., 2005 .(Age has a positive impact but its contribution is very small )0.09.(\%Findings suggest that as firms get older they discover their expertise, take the benefits of learning, improve quality and reduce cost, so a positive relationship between age and profitability is expected (Majumdar, 1997). The only firm specific variable in this model that has no significant effect on the profitability is capital intensity .This insignificant relationship may be due to the reason that most of the sample firms are not highly capital intensive . Empirical finding of )French and Fama, 2000 (about capital intensity is similar. Year and stable industry effect is observed insignificant but transient industry effect is significant .Total industry effect is $0.18 \%$ in profitability explanation .Our results about the effect size of industry give empirical support to the findings of (Wiggins and Ruefli, 2003), that industry effect is only $0.1 . \%$

المجلا الحادي عشر


The Effect of Industry Specific Factors on the Profitability of Companies...

DR/ Ahmed Fouad Hassaballa \& Shereen Fadel Fahmy Bishara

\section{4- Sample of the Research}

The researchers applied the research on Egyptian companies listed in the Egyptian Stock Exchange Market .The sample of the study included all the companies listed in the Case 30 index . They included a total of 30 companies, however, the researchers disregarded any companies belonging to the banking industry, since banks are heavily regulated and follow different regulations when compared to other industries .There was only one bank in the Case 30 index, the Commercial International Bank of Egypt (CIB )and this bank was excluded from the research, leaving a total of 29 companies .

The research covered a period of four years from the year 2006 to the year 2009 .The researchers gathered secondary data concerning the financial statements and ratios of the 29 companies in the sample from Coface for Information and Economic Consultants Services(S.A.E.)

\section{5- Model Testing Company Profitability}

The objective of the research is to test for a profitability model, that when used effectively by corporations could increase profitability to the utmost and at the same time to test for the effect of industry specific factors on firm profitability. The model of the study is represented as follows:

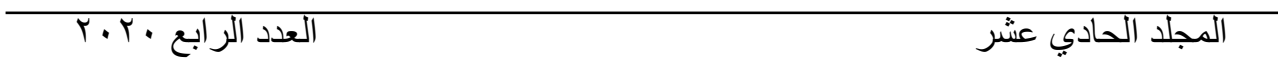


The Effect of Industry Specific Factors on the Profitability of Companies...

DR/ Ahmed Fouad Hassaballa \& Shereen Fadel Fahmy Bishara

$$
\begin{aligned}
R O A_{T}=a & +\operatorname{LogTA}_{t}+\operatorname{Lev}_{t}+\operatorname{Age}_{t}+\operatorname{Liq}_{t}+M S_{t}+G R_{t} \\
& +\operatorname{Ind}(R E)_{t}+\operatorname{Ind}(\operatorname{Inv} C)_{t}+\operatorname{Ind}(P \& H H)_{t} \\
& +\operatorname{Ind}(T \& L)_{t}+\operatorname{Ind}(C \& M)_{t}+\operatorname{Ind}(\text { TeleC })_{t} \\
& +\operatorname{Ind}(\operatorname{inds} G)_{t}+\operatorname{Ind}(\text { Chem })_{t}+\operatorname{Ind}(F \& B)_{t} \\
& +\operatorname{Ind}(B R)_{t}+e
\end{aligned}
$$

The dependent variable of the research is the ratio return on assets, which measures the percentage of profits generated from total assets.The researchers decided that return on assets is a better measure for profitability than return on equity, since an analysis of return on equity disregards financial leverage and the risks associated with it, thereby not supporting an appropriate measure for profitability. The independent variables will include the following variables:

LogTA represents the size of the companies involved in the research .Size is determined by the amount of total assets listed by each and every company .Total assets could be considered as the most efficient item that accurately measures company size, since it includes all the company's trading and investments, both in the short and long term .The researchers, however, measured the variable size by finding the logarithm of total assets . They used the variable logarithm of total assets in order to normalize data and to unify the unit of measurement of all variables in order that they may be small in figures and not in millions like is the case with total assets.

المجلد الحادي عشر


The Effect of Industry Specific Factors on the Profitability of Companies...

DR/ Ahmed Fouad Hassaballa \& Shereen Fadel Fahmy Bishara

The variable $L e v_{t}$ represents the amount of debt used by the companies listed in the Case 30 index, both current and long term debt .This variable was measured by determining the debt ratio used by the companies.

The variable $\mathrm{Age}_{t}$ represents the number of years the companies have been in existence. The researchers believed that the number of years the companies have been in existence is a better measure of experience than the length of time the companies have been listed in the stock market and an even better measure than the length of time the companies have been privatized .

The variable $\mathrm{Liq}_{t}$ represents the liquidity of the companies in the sample of the research .Liquidity was measured by the variable current ratio, which determines the number of times current assets are covered by current liabilities.

The variable $M S_{t}$ represents the market share of the companies in the sample of the study. This was determined by the percentage of trading volume to market volume.

The variable $G R_{t}$ represents the growth rate of the companies in the sample. Growth rate was calculated by determining the percentage change in sales from one year to the next.

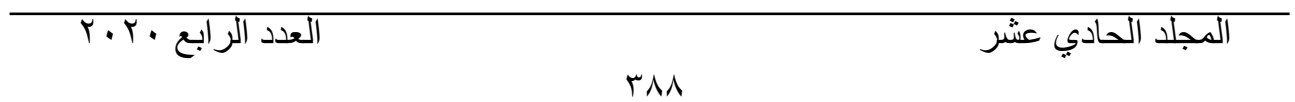


The Effect of Industry Specific Factors on the Profitability of Companies...

DR/ Ahmed Fouad Hassaballa \& Shereen Fadel Fahmy Bishara

Ind $_{t}$, in the model of the study, represents the different industries that the companies listed in the Case 30 index belong to .Overall the companies in the index where divided into10 industries namely :the Real Estate industry, the investment industry, the personal and household industry, the travel and Leisure industry, the construction and materials industry, the telecommunications industry, the industrial goods industry, the chemicals industry, the food and beverage industry and the basic resources industry .These industries were added as dummy variables given the values of zero " 0 "and " $1 . "$

The subscript $t$, was used to represent the period of the research, which was conducted over a period of 4 consecutive years, from the year 2006 to the year 2009.

The variable e in the model of the study represents the error of the model.

\section{6- Correlation Matrix}

The researchers performed a correlations matrix to determine the individual effect of each and every variable in the model of the study on firm profitability .All the industries in the sample were found to significantly affect firm profitability, except the Investment industry, the telecommunications industry, the industrial goods industry, the chemicals industry and the food and beverage industry .All the other industries were found to

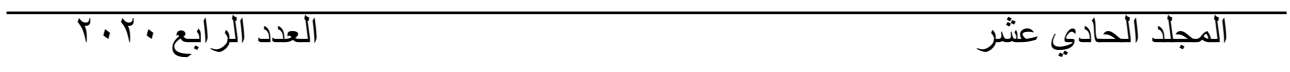


The Effect of Industry Specific Factors on the Profitability of Companies...

DR/ Ahmed Fouad Hassaballa \& Shereen Fadel Fahmy Bishara

significantly affect return on assets .All industries were determined to positively affect ROA, except the Real estate industry and the personal \& household industry which were determined to negatively affect profitability in a significant way.

The correlation matrix also showed that most of the other variables in the model of the study were not found to significantly affect firm profitability, and this was attributed to the presence of multicolinearity, which indicates that there is a significant relationship between many of the independent variables represented in the model of the study .As a result, the researchers went ahead and performed the multiple regression analysis on the data to prevent bias in the results .

\section{7- Regression Analysis}

The researchers performed the multiple regression analysis on the data present in the model of the study and the following results were determined:

$+(\mathrm{P} \& H H) 3$ Ind.11 - (InvC)98 Ind.7 - (RE)7 Ind.10 -94 .3 =ROA (T\&L) 44 Ind.3

85.3 - (indsG)74 Ind.7 - (TeleC)58 Ind.5 - (C\&M)16 Ind.0 +

(Chem)Ind

167.0 -0128 Age .0 - 41 LogTA.2 + (F\&B)80 Ind.4 -

Leverage

03 Growth rate. $1+236$ Market share .0 - 169 Liquidity .0 -

المجلد الحادي عشر العدد الرابع •r.r. rq. 
The Effect of Industry Specific Factors on the Profitability of Companies...

DR/ Ahmed Fouad Hassaballa \& Shereen Fadel Fahmy Bishara

\section{Table 1 - Multiple Regression}

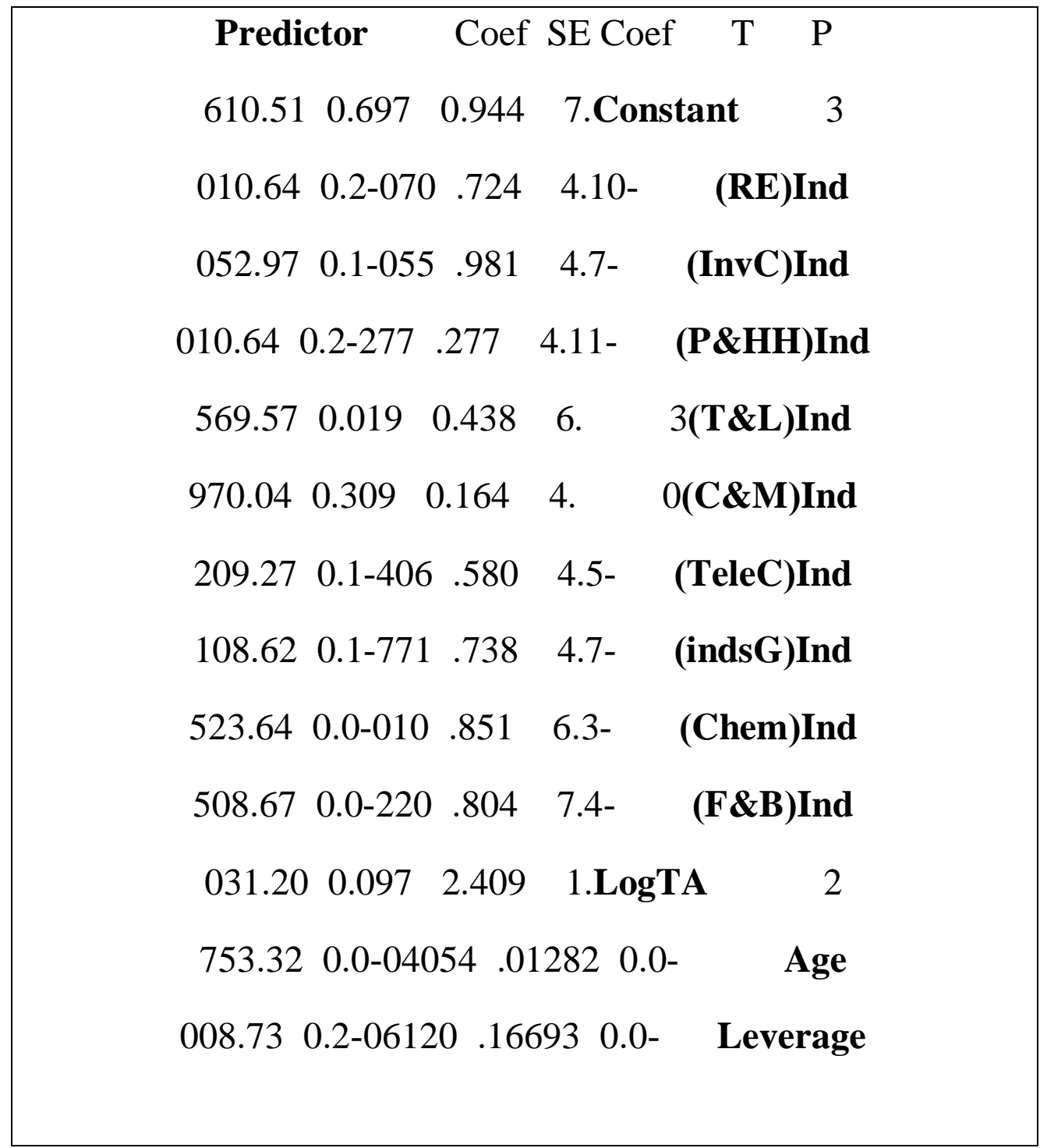

\footnotetext{
المجلد الحادي عشر
} 
The Effect of Industry Specific Factors on the Profitability of Companies...

DR/ Ahmed Fouad Hassaballa \& Shereen Fadel Fahmy Bishara

\begin{tabular}{|rllll|}
\hline 730.35 & $0.0-4880$ & .1693 & $0.0-\quad$ Liquidity \\
523.64 & $0.0-3685$ & .2365 & $0.0-$ & Market share \\
135.51 & 0.6836 & 1.0325 & $0 . G r o w t h$ rate $\quad 1$ \\
$\% 6.30=(\operatorname{adj}) \mathrm{Sq}-\mathrm{R}$ & $\% 3.41=\mathrm{Sq} \mathbf{- 9 3 4 4 3} \quad \mathrm{R.8}=\mathrm{S}$ \\
\hline
\end{tabular}

Table 2 - Analysis of Variance

$\begin{array}{llllll}\text { Source } & \text { DF } & \text { SS } & \text { MS } & \text { F } & \text { P }\end{array}$

$002.67 \quad 0.47 \quad 2.98 \quad 213$. Regression $\quad 15 \quad 3201$

82.51 79.Residual Error $88 \quad 7024$

50.Total 10310226

As can be seen from the tables above, the real estate industry, the personal \& household industry, the investment industry, were the only industries found to significantly affect firm profitability . All these industries were found to negatively affect firm profitability .Also the results showed that the variables size and leverage were the only two variables found to significantly affect ROA . Size was found to positively affect firm profitability, while leverage was found to negatively affect firm profitability. The overall model of the study was found to explain $41.3 \%$ of the changes in firm profitability and the model of the study was very significant, depicting a P-value of 0.002 .

المجلد الحادي عشر


The Effect of Industry Specific Factors on the Profitability of Companies...

DR/ Ahmed Fouad Hassaballa \& Shereen Fadel Fahmy Bishara

However, since the data of the study showed the presence of multicolinearity and therefore bias in the results, the researchers went ahead and performed the stepwise regression analysis, which is more accurate than the normal multiple regression test, since it eliminates the presence of multicolinearity from the data . The following results were obtained:

\section{Table 3 - Stepwise Regression}

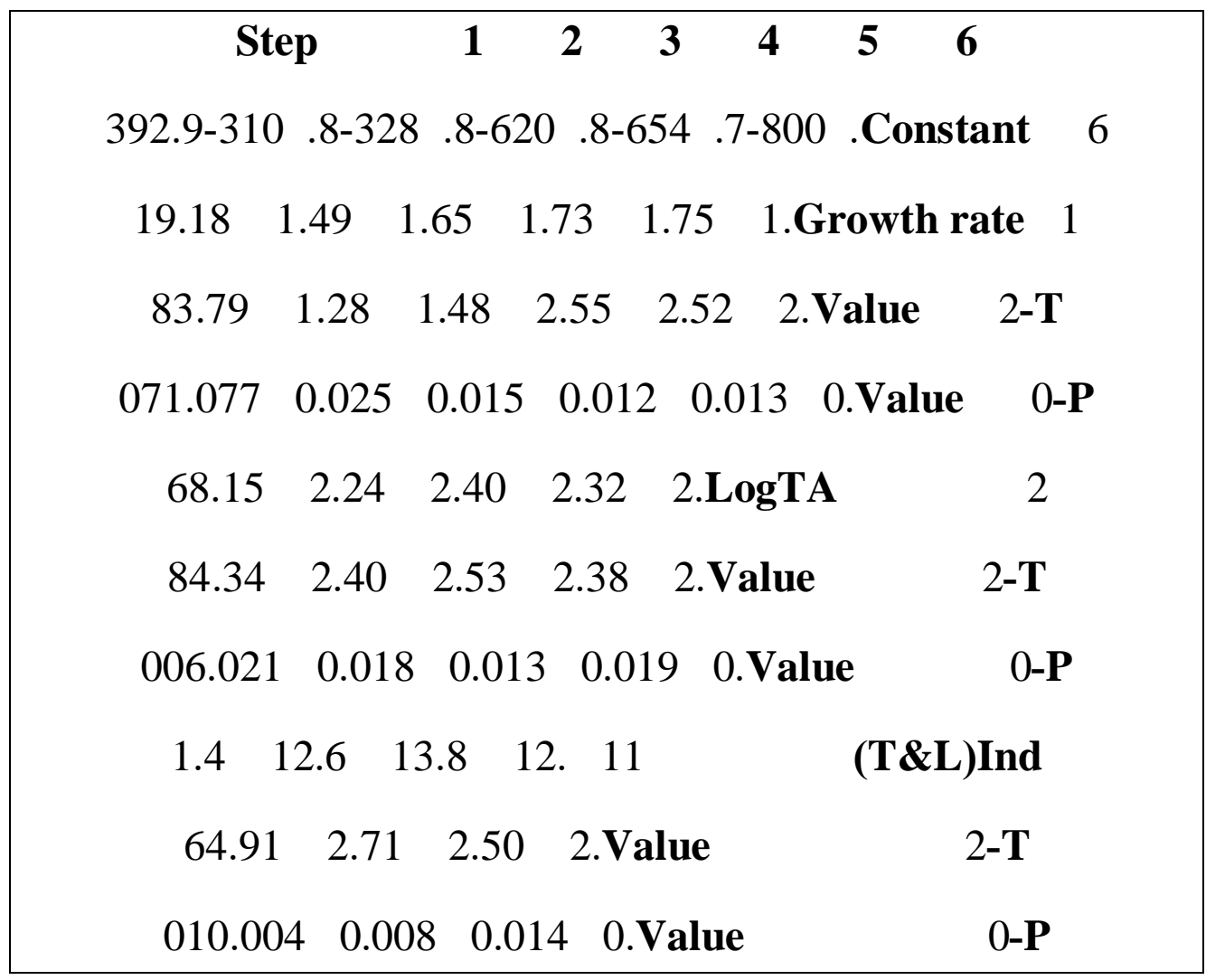

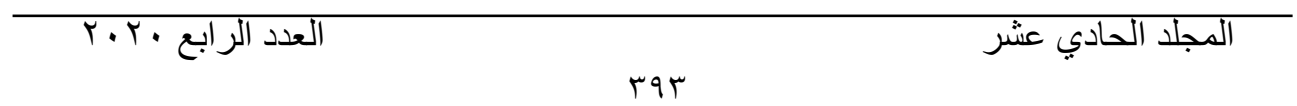


The Effect of Industry Specific Factors on the Profitability of Companies...

DR/ Ahmed Fouad Hassaballa \& Shereen Fadel Fahmy Bishara

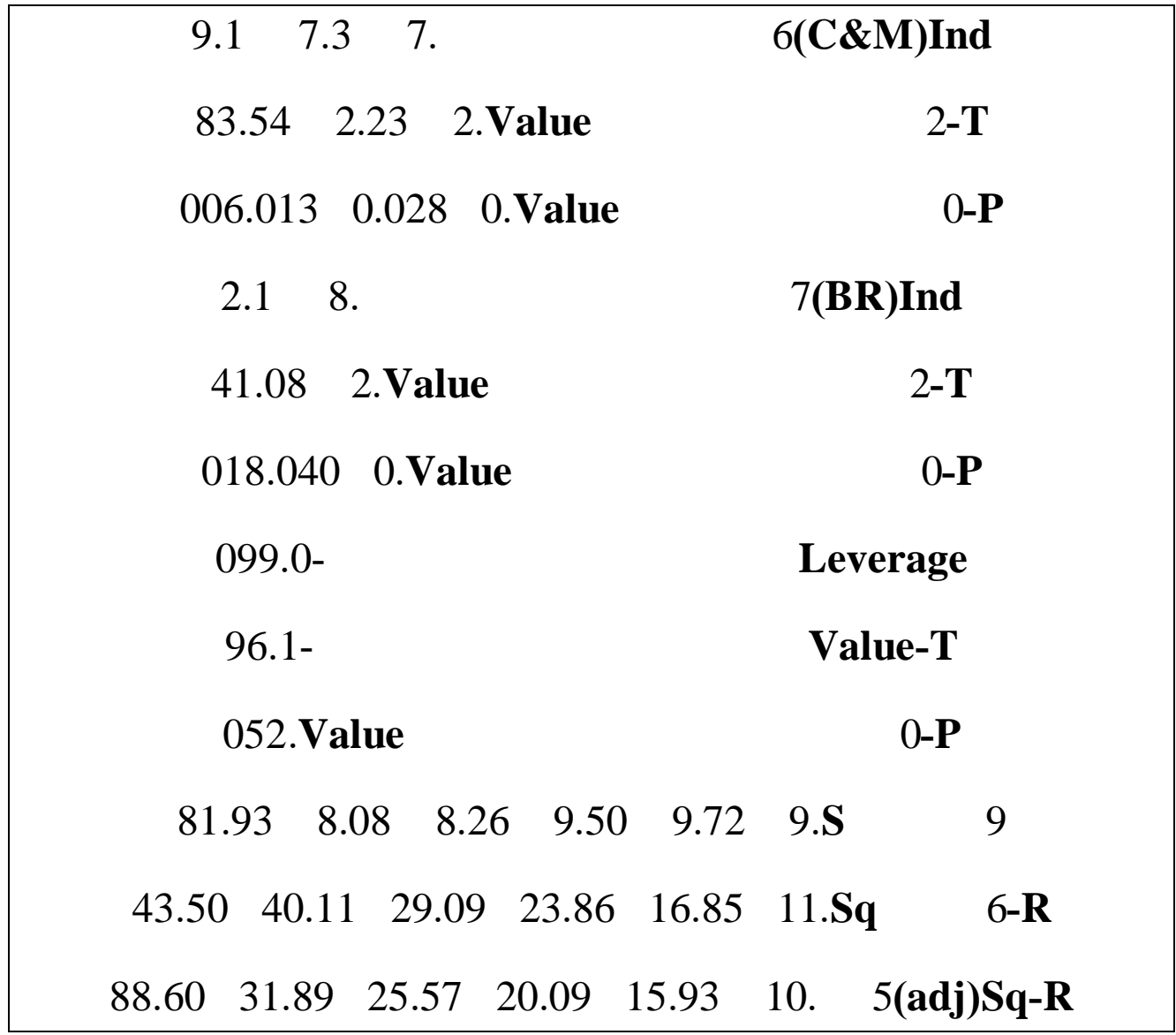

Based on the stepwise regression tests, the variables found to significantly affect firm profitability were growth rate, size, the travel \& leisure industry, the construction \& materials industry, the basic resources industry and leverage.

Growth rate was determined to positively affect ROA and this is an indication that as a company or firm increases its sales, it is

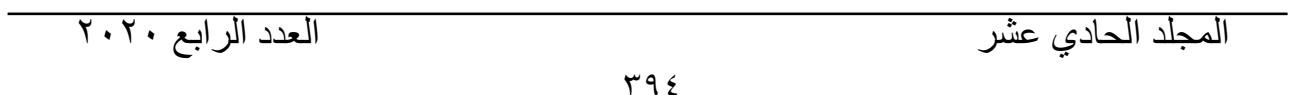


The Effect of Industry Specific Factors on the Profitability of Companies...

DR/ Ahmed Fouad Hassaballa \& Shereen Fadel Fahmy Bishara

likely to increase its operations in profitable investments and therefore generate more profits .The variable growth rate alone was determined to explain $6.85 \%$ of the changes in firm profitability.

Size was also found to positively affect ROA, likewise indicating that as a company increases its investments in total assets, it is likely to increase its operations in profitable investment opportunities and increase profits .Both the variables growth rate and firm size were determined to explain $11.86 \%$ of the changes in firm profitability.

The travel \& leisure industry, the construction \& materials industry and the basic resources industry were all found to positively affect ROA . This indicates that these industries have a very active role in determining firm profitability, in other words, the concept of the industrial organization exists in the Egyptian securities market .All these industries along with the variables growth rate and firm size were found to explain $29.5 \%$ of the changes in firm profitability .

According to the results obtained from the stepwise regression, the variable leverage was found to negatively affect ROA .This is an indication that as a firm borrows more debt, its profitability is likely to decrease, and this could be attributed to the high cost of debt incurred by the firm .More leverage serves to increase firm liquidity, however it could also increase the cost of debt that has

المجلد الحادي عشر العدد الرابع •r.r.


The Effect of Industry Specific Factors on the Profitability of Companies...

DR/ Ahmed Fouad Hassaballa \& Shereen Fadel Fahmy Bishara

to repaid by the firm to its creditors. This could end up by having a negative effect on firm profitability. The variables growth rate, firm size, the travel \& leisure industry, the construction \& materials industry, the basic resources industry and leverage were determined to explain $40.43 \%$ of the changes in firm profitability .

\section{9 -ANOVA Test}

The researchers went a step further and performed the ANOVA test to determine if firm profitability significantly changes given the different variables in the model of the study .The variables size, age, leverage, the real estate industry, the personal \& household industry, the travel\& leisure industry, the construction \&materials industry, and the basic resources industry were found to significantly affect ROA. The results are represented in the following tables below:

\section{ROA versus LogTA :way ANOVA-One -Table 4}

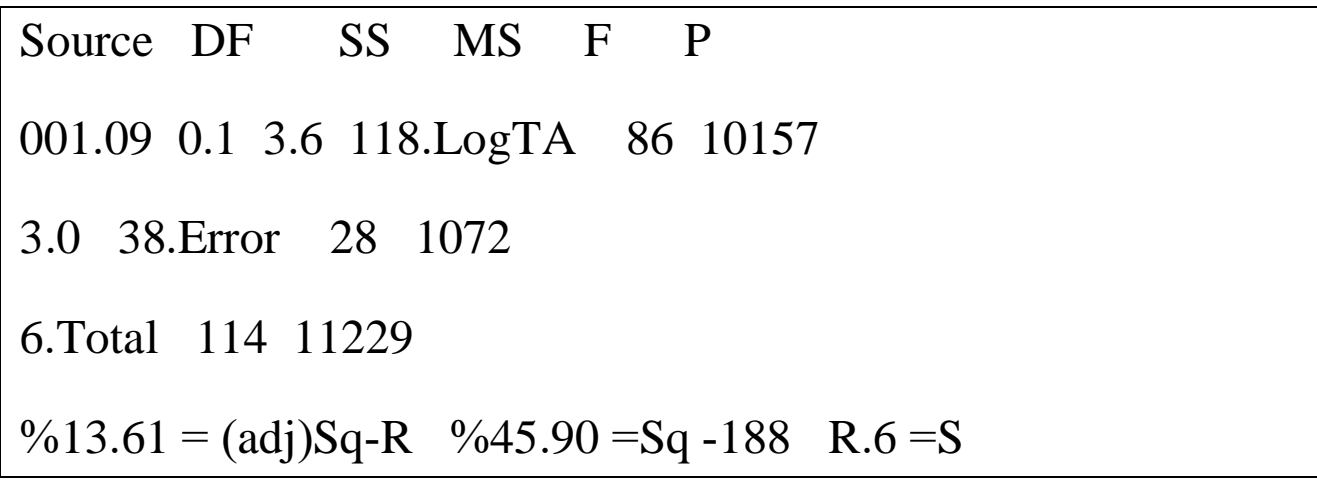

المجلد الحادي عشر


The Effect of Industry Specific Factors on the Profitability of Companies...

DR/ Ahmed Fouad Hassaballa \& Shereen Fadel Fahmy Bishara

ROA versus Age :way ANOVA-One -Table 5

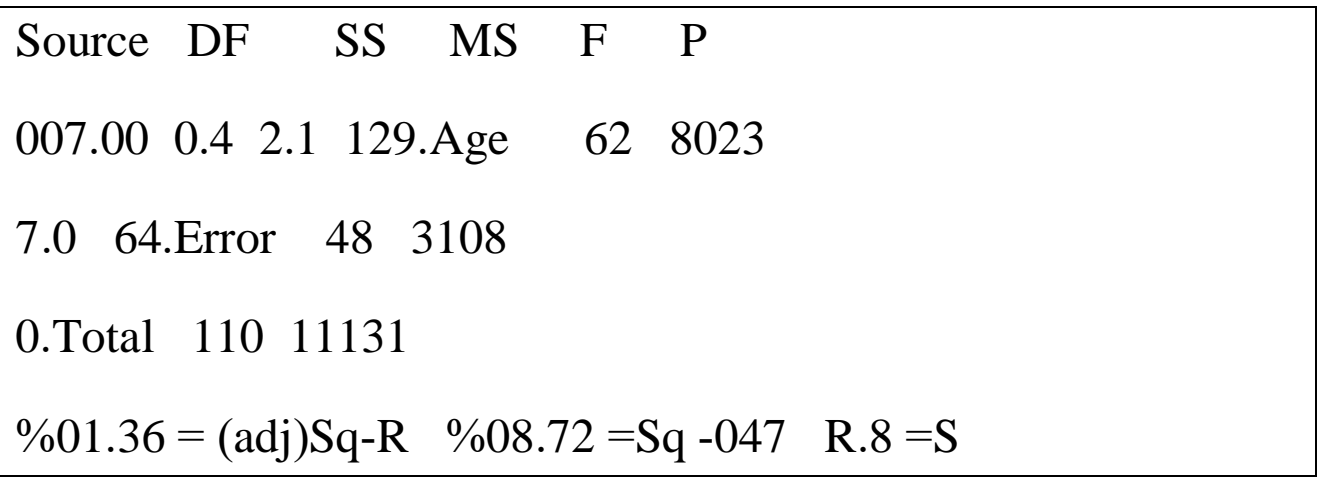

ROA versus Leverage :way ANOVA-One -Table 6

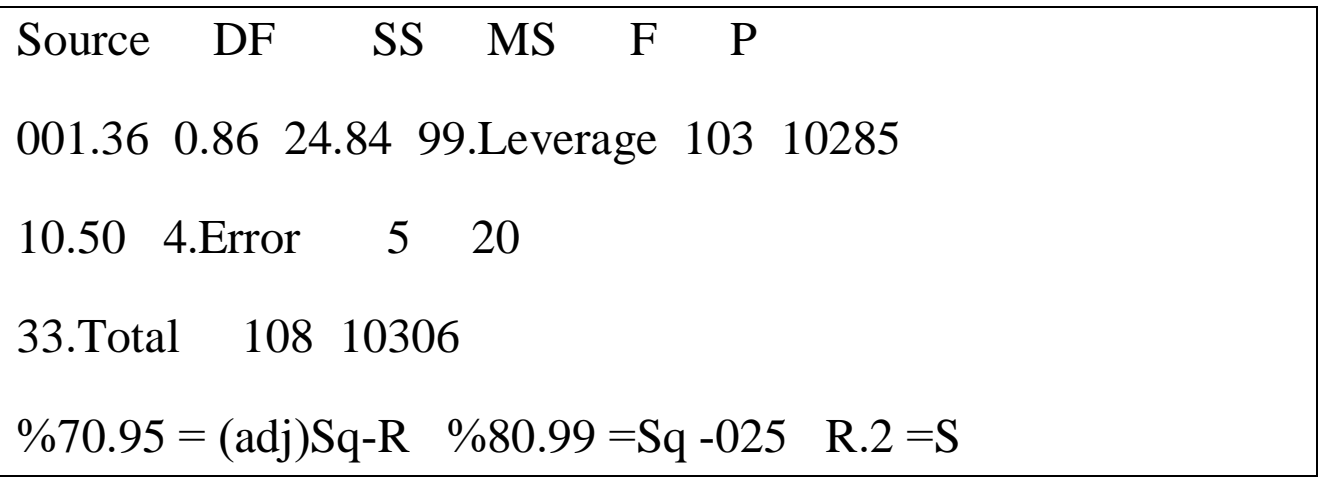

(RE)ROA versus Ind :way ANOVA-One -Table 7

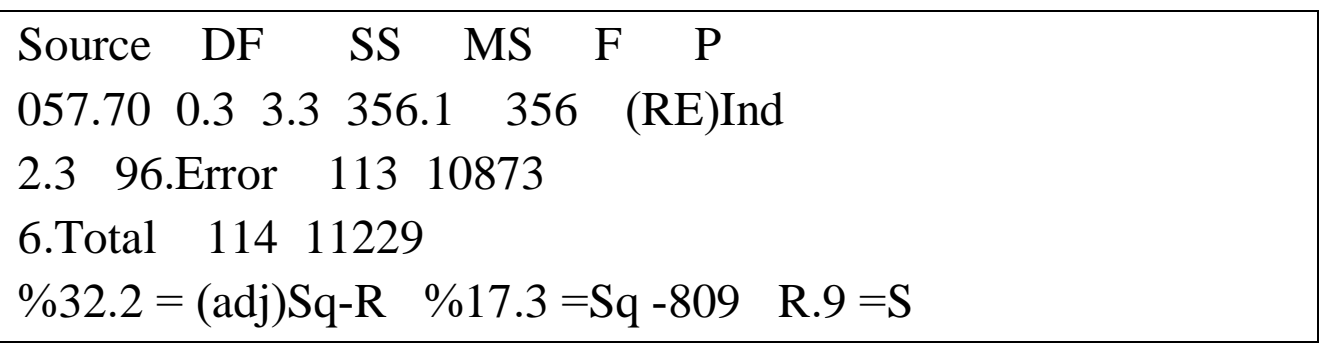

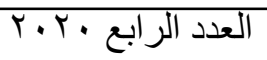

المجلد الحادي عشر 
The Effect of Industry Specific Factors on the Profitability of Companies...

DR/ Ahmed Fouad Hassaballa \& Shereen Fadel Fahmy Bishara

(P\&HH)ROA versus Ind :way ANOVA-One -Table 8

\begin{tabular}{|c|c|c|}
\hline Source $\quad$ DF & SS $\quad$ MS & $\begin{array}{ll}\mathrm{F} & \mathrm{P}\end{array}$ \\
\hline $\begin{array}{lll}054.51 & 0.3 & 3.3\end{array}$ & $\begin{array}{lll}3 & 338.1 \quad 338\end{array}$ & (P\&HH)Ind \\
\hline 4.4 96.Error & 11310891 & \\
\hline 6.Total 114 & 11229 & \\
\hline
\end{tabular}

(T\&L)ROA versus Ind :way ANOVA-One -Table 9

Source DF $\quad$ SS $\quad$ MS $\quad F \quad$ P

$\begin{array}{llllll}012.58 & 0.8 & 6.8 & 617.1 & 617 & \text { (T\&L)Ind }\end{array}$

9.8 93.Error 11310611

6.Total 11411229

$\% 67.4=(\operatorname{adj})$ Sq $-\mathrm{R} \quad \% 50.5=\mathrm{Sq}-691 \quad \mathrm{R} .9=\mathrm{S}$

(C\&M)ROA versus Ind :way ANOVA-One -Table 10

Source DF $\quad$ SS MS F P

$\left.\begin{array}{llllll}011.67 & 0.5 & 6.5 & 625.1 & 625 & (\mathrm{C} \& M)\end{array}\right)$ Ind

8.2 93.Error 11310604

6.Total 11411229

$\% 73.4=(\operatorname{adj})$ Sq-R $\% 57.5=$ Sq $-687 \quad$ R.9 $=\mathrm{S}$ 
The Effect of Industry Specific Factors on the Profitability of Companies...

DR/ Ahmed Fouad Hassaballa \& Shereen Fadel Fahmy Bishara

(BR)ROA versus Ind :way ANOVA-One -Table 11

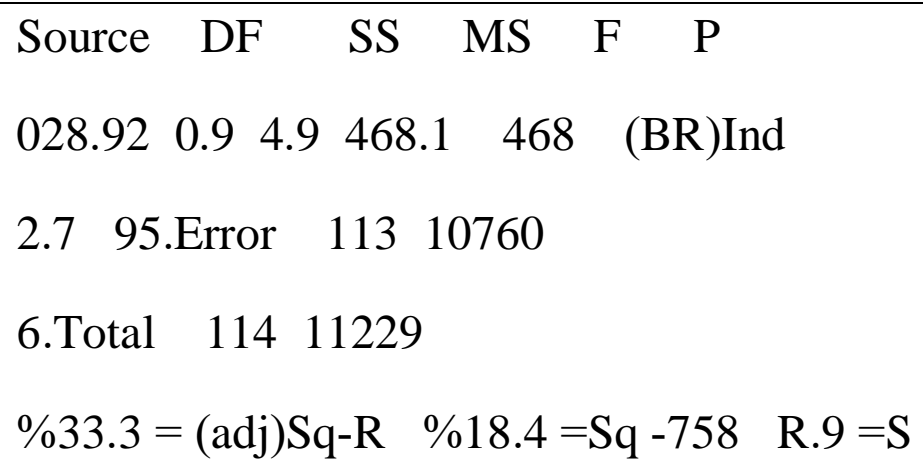

As can be seen from the tables above, variable firm size was determined to significantly affect firm profitability and to explain $61.13 \%$ of the changes in ROA .Age was found to significantly affect ROA and to explain $31.01 \%$ of the changes in firm profitability .Likewise, leverage was found to explain $95.7 \%$ of the changes in profitability. Also five of the industries in the sample of the study were found to significantly affect profitability .

To further test for the effect of the industrial organization, the researchers tested the sample of the study again by isolating all other variables that may affect ROA, except for the effect of industries .The results obtained indicated that industries alone explain about $31.3 \%$ of the changes in firm profitability, supporting the concept of the industrial organization .

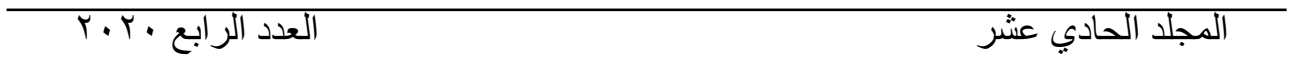


The Effect of Industry Specific Factors on the Profitability of Companies...

DR/ Ahmed Fouad Hassaballa \& Shereen Fadel Fahmy Bishara

\section{Conclusion -10}

The findings of the research indicate that there is strong evidence in support of the industrial organization in the Egyptian market .It is also evident that as firms increase their sales and increase their investments in total assets, they are likely to, in turn, increase their profitability .The test findings also indicate that there is a negative relationship between leverage and firm profitability due to the high cost of borrowing .

Liquidity was not found to have any significant effect on profitability and this could be attributed to the current ratio being an important variable affecting liquidity and not profitability .If liquid assets are not invested wisely, firms will not be able to increase profitability .Likewise, market share was not found to have a significant effect on profitability and this could be attributed to the concept that a company's trading of shares in the market is not an indication of higher profitability . 